\title{
Anthrovision
}

Vaneasa Online Journal

\section{Visual Methods to Study the Underwater World}

Scuba Divers and a Sensorial Experience of Water

\section{Rasmus Rodineliussen}

\section{(2) OpenEdition \\ Journals}

Electronic version

URL: http://journals.openedition.org/anthrovision/2910

DOI: 10.4000/anthrovision.2910

ISSN: 2198-6754

Publisher

VANEASA - Visual Anthropology Network of European Association of Social Anthropologists

\section{Electronic reference}

Rasmus Rodineliussen, «Visual Methods to Study the Underwater World », Anthrovision [Online],

5.2 | 2017, Online since 31 December 2018, connection on 02 May 2019. URL : http://

journals.openedition.org/anthrovision/2910; DOI : 10.4000/anthrovision.2910

This text was automatically generated on 2 May 2019.

(c) Anthrovision 


\section{Visual Methods to Study the Underwater World}

Scuba Divers and a Sensorial Experience of Water

\section{Rasmus Rodineliussen}

Image from a dive boat in Arraial do Cabo, Brazil.

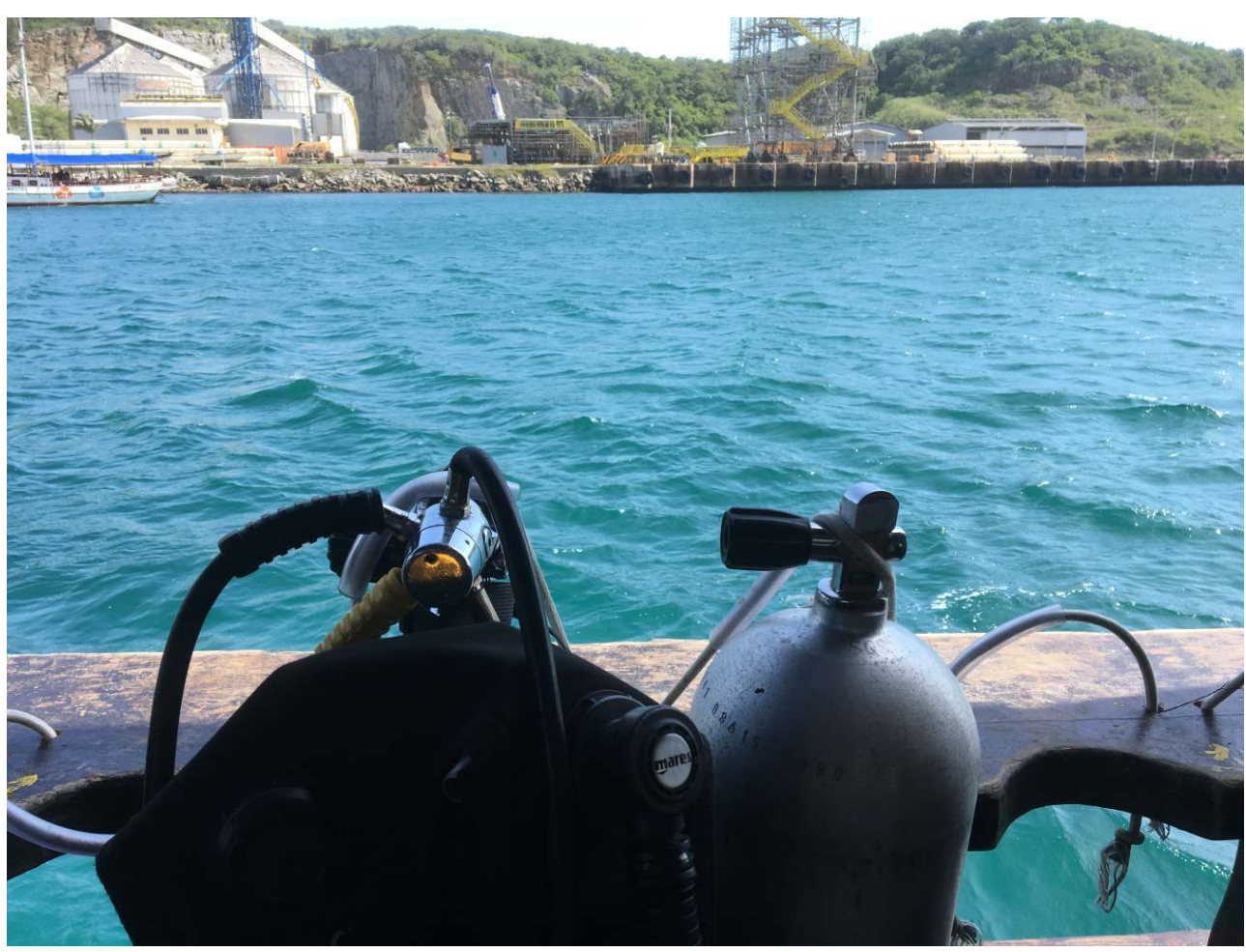

Photo by Rasmus Rodineliussen.

Visual methods are incredibly useful both for collecting ethnographic data and to spur dialogues with interlocutors around data and the method itself. In this article I intend to make us all a little bit wet, we will dress in a wetsuit, put a pair of goggles on, and jump 
into the watery blue bringing the visuals with us as a tool and a body part. I will let the digital scholar Paolo Favero set the scene for what is to come:

[...] when the camera is not guided by the intentionality of the filmmaker, but rather by its various engagements with the materiality of the elements surrounding it - the bodies of the fishermen, the flow of the water etc. Inviting users to engage with the physicality of the world surrounding them, the GoPro opens up an interesting and intimate dialogue between body and matter, body and body. (Favero 2017: 12)

This dialogue is what I try to grapple with in this article, while searching for means to document the process of diving itself. I will first introduce the scuba diving community and reasons for why it should be a focus for academic scrutiny. Then I will outline the bodily sensorial experience of being under water, before turning to technologies of documentation and how visual methods offer ways to document, experience, and understand this environment and its practices . Lastly I conclude by reflecting on how visual data, from land or water, are entangled in a complicated discourse on representation and power. My argumentation and ethnographic knowledge is drawn from fieldwork late 2016 to early 2017 among divers in Rio de Janeiro and Arraial do Cabo, Brazil. As well as my own decade long experience from being a so-called recreational diver. ${ }^{1}$

\section{Scuba Divers - A Global Community}

There is a growing literature on the relationship between scuba divers and tourism (e.g: Lück 2015; Musa and Dimmock 2012; Merchant 2011a \& b) and the environment (e.g., Hawkins, Roberts, Kooistra, Buchan and White 2005; Musa and Dimmock 2012; Rodineliussen 2017). Yet, there is a scarce understanding and literature of and on how to do social research with human subjects under water - this is the topic of concern here.

Before indulging into methodological aspects of what I call underwater ethnography, let's start with some context around the social group of scuba divers. There is no consensus on how large the diving community really is - although some estimates suggest there were about 22 million certified divers in 2014 (Lück 2016: 259). The uncertainty is because not all of the leading dive schools publish the number of certified divers they have. And those that do publish all certificates they give out annually take no account of if the certificate is a diver's first entrance into the sport or if it is the same diver that take three or four certificates during one year. Thus, counting the number of active divers in the world is all but impossible. However, to get a feeling about possible numbers I can mention that PADI (Professional Association of Diving Instructors), the biggest dive school globally, say that they average $900^{\prime} 000$ certificates annually - here they do not specify what type of certificate. ${ }^{2}$ Another example is that in the dive school in Arraial do Cabo where I spent most time during my fieldwork in Brazil they certificate 120 new divers annually. Keep in mind that this is one school out of 10-15 in one small tourist village of close to 30,000 inhabitants, meaning that there are probably around 1000-1500 new divers certified in this town alone during one year. Without knowing the exact numbers, we can still conclude that the diving community is large, and it is global - PADI alone is active in 190 countries worldwide.

Scuba divers as a group are interesting to study because although they come from all corners of the world, and from somehow different economic backgrounds (the price of scuba diving tends to attract mostly middle-class) they all share a passion for water and 
the marine environment. Moreover, a strong uniting factor is the fact that about 70 per cent of the world's geographical area is below water, and scuba divers are the only humans roaming this space on a regular basis. When you arrive to a new destination especially a tourist one - you can always stick your head into the first dive shop and find 'friends' for the sole reason that you are a diver. This community spirit among divers, and their fascination for a hard-to-reach environment is what makes them so interesting for me as a social anthropologist.

\section{Why Making Ethnography Below the Surface?}

6 In a 2018 article in Anthropology Today Bengt G. Karlsson ask scholars within political ecology to engage nature in a new way. He emphasizes the need to include the agency of nature and animals in the equation when politicizing the relationship between human societies and their surroundings in the era of the Anthropocene (see further Harraway et.al 2015). In this article Karlsson (2018) discuss the novel and intriguing book Becoming Salmon, written by Marianne Lien (2015). Karlsson outlines the many benefits of Lien's work and the contribution she makes to anthropology and to the study of human-nature relations. Yet, he does also question why she never enters the habitat of the fish that she studies - a critique I agree with. As Wacquant (2004: 59) has it, in order to understand practices one has to practice them oneself - and how better to understand the social life of fish and their relationship with humans then submerging into their environment, becoming a participant-observer from below the surface. This argument is strong when applied to the case of scuba divers. This is because by conducting participant-observation under water it is possible for the researcher to follow first hand the way divers dive, how they interact with each other, with animals, and nature. Divers can make big contributions to the marine environment by carefully removing debris by hand and documenting species, keep an eye on the state of corals etc. But they can also endanger this environment by reckless diving practices such as touching and removing corals - by purpose or accidentally. When observing a researcher can grasp these nuances in how divers actually dive and interact with the marine environment. Were the researcher to stay on the surface and rely on post-dive interviews these nuances would easily be left below the surface and out of reach for the researcher. Let me give an example from a dive in Brazil, or more specifically, the surface-interval between two dives that day.

We hovered at 3 meters below surface, waiting for the 5 minutes of equalization to end before resurfacing. I was fully occupied with thinking about two of the divers in the group. They had behaved so strangely, if not to say badly. During our dive they had been staying on corals, they grabbed clams with their hands, and stirred up sand in all directions, making it complicated for the rest of us to see anything. I thought I had to speak to them about the way they dived, it was really not OK.

On the boat, after losing the gear all divers sat down and started to talk about the experience of the dive, what we had seen, how the visibility was, and so on. I was only about to ask one of the divers with the strange diving behaviour about the last dive when one of them took the word. "For the next dive I must bring my gloves, all these corals are so sharp, I end up cutting myself." To this another diver responded "well, you could always stop touching the corals?". The first speaker responded "How do you dare say so to me, I have so much diving experience from years and years of diving. I know how to dive better than you!"

This example illustrates how it is important to both observe and hear what people say. It is clear that the diver with the 'bad' diving habits clearly is not able to dive according to 
the book. However, he uses his 'capital' of many years of experience to strike back at anyone questioning his skills. Social capital, embodied skills, and the environment are here in an entangled relationship, and without following this relationship from all angels, a sort of holistic approach, it will be hard to know how to analyse the social processes at play between diver and diver as well as between diver and environment (for reading on social capital and embodied skills see eg. Bourdieu 1990; Broady 1991; Waqcuant 2004).

This image shows a nudibranch outside of Crete, Greece.

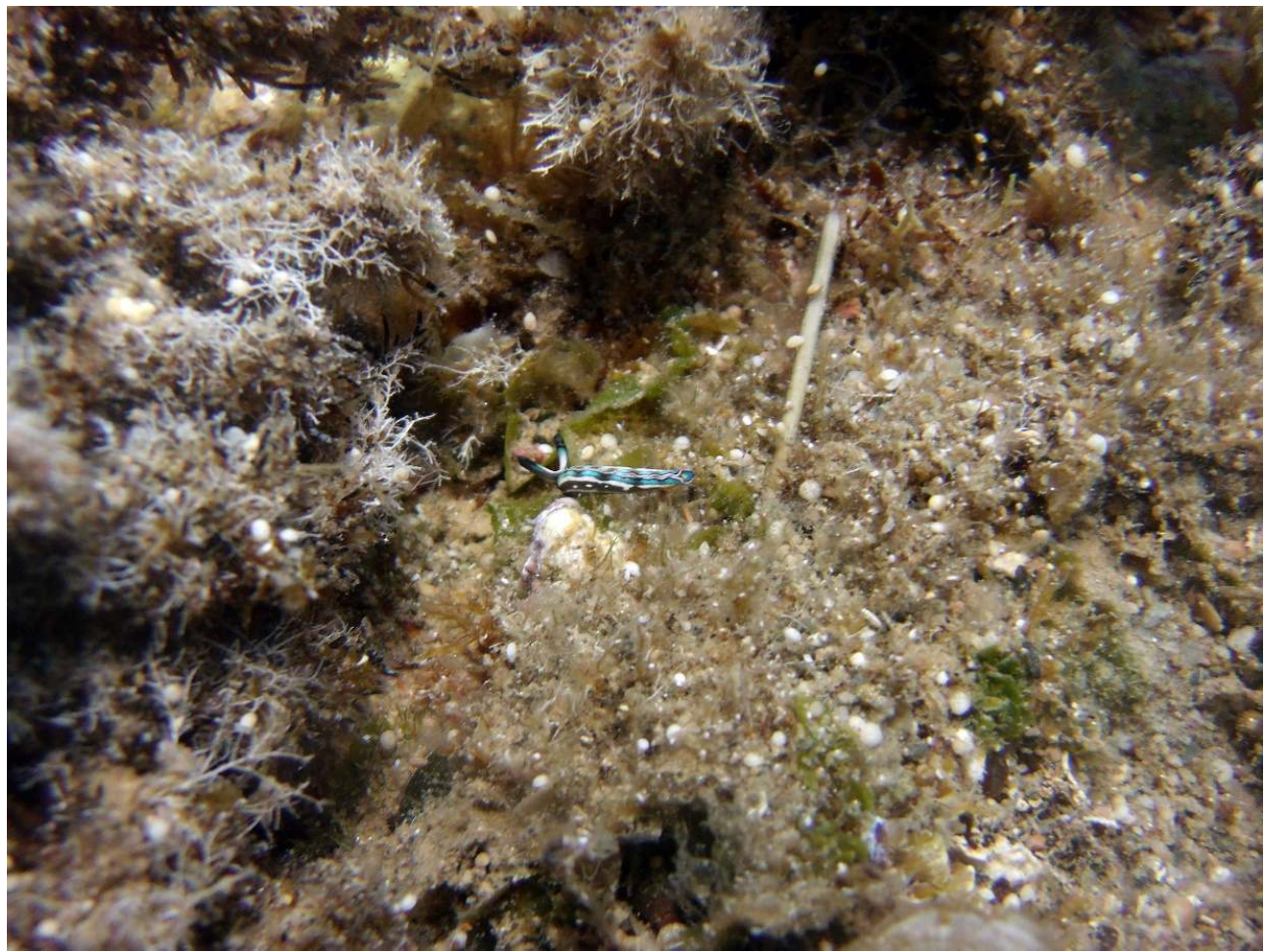

Photo by an anonymous dive master

\section{Submerging Into the Blue World}

Merchant (2011a) describe diving as a "special sensory experience", meaning that when submerging into water wearing scuba gear such as $B C D^{3}$, Regulator, fins, and dry/wetsuit the body become weightless, it can keep warm longer in water, and can move faster and with less effort. All this contributes to the "strangeness of this experience for the body" (Merchant 2011a; Rodineliussen 2017). Without actually experiencing this changing environment, and how it affects the body as time goes during a dive it is hard to assess how divers act and think under water (on sensorial experiences: Herzfeld 2007; Stoller 1989, 1997). One of the main distresses a diver meets regularly under water is getting cold. To illustrate let me give you an example. It was an early 2016 January morning on Malta, in the capital city Valletta. I, an instructor, and another diver were set to do a wreck dive. Malta is one of the great dive destinations of Europe, and most of the year the water is warm and pleasant - only not in January. We had chilling 13 degrees Celsius, and there were only wetsuits (in colder countries dive centres tend to offer dry suits that keeps the water out), meaning that the 13-degree cold water had to enter our suits, and stay between our skin and the suit for our bodies to warm the water before it could help 
our bodies to stay warm in the water. I was freezing before we even started our decent. The dive lasted for about 40 minutes, and all I could think of was "when will it end??". I do not remember the wreck, nor anything else for that matter, all my memories from this dive is about shivering cold, blue hands, and the intense feeling of relief when exiting the water. Being in cold water is tremendously tiring for a diver, and it can really cause panic because you cannot just swim up. Due to decompression reasons you must stay below surface for a certain amount of time, and this makes the cold feel much more real - you cannot escape.

During these circumstances, when the body shivers from cold, the mind is getting tired from staying calm and alert to the ever changing marine environment and landscape. Then it is much more likely that the diver accidentally loses control over their buoyancy and kick a coral with the fin, or grabs a rock by the hand to find support - a rock that then falls down and crushes something on the bottom. If a researcher has never been in this environment, never sensed this physical state of the body, then it is close to impossible to understand the bodily reactions and their possible effects on the environment as well as the mental state of the diver. Bodily experiences are best understood using your own body (Waqcuant 2004). However, although I argue it is essential for a researcher wanting to study divers to do so partly under water, it is as Merchant (2011b) writes, important to not over emphasize what the researcher can understand simply by experiencing this environment. Although it is important to understand how a body reacts to being under water, it is also a fact that all bodies react differently and therefore a researcher cannot understand the exact feelings another diver would experience, similar yes, but not identical. And therefore underwater observation ought to be part of a larger research methodology on a par with on-land observations and interviews.

Understanding dive practices become easier if the researcher also collects some background on the interlocutors, because practices develop in relationship to already embodied knowledge of the practitioners and with the environment. Thus, by understanding earlier dive experience and beliefs of the diver it is more comprehensible to analyse how certain practices develop, and why specific decisions were made under water (Gherardi 2016). All divers have a logbook wherein most dives are logged, and if the dive was conducted with a guide the book is also stamped and signed by the dive master/ instructor. This book provides information on the location and time of the dive, how deep and long the dive was, what temperature and visibility, and sometimes if specific observations have been made. Thus, discussing this book with interlocutors, asking about their memories from the different dives can provide further knowledge about earlier experiences of the diver and thereby give the researcher some background to understand future actions with. 

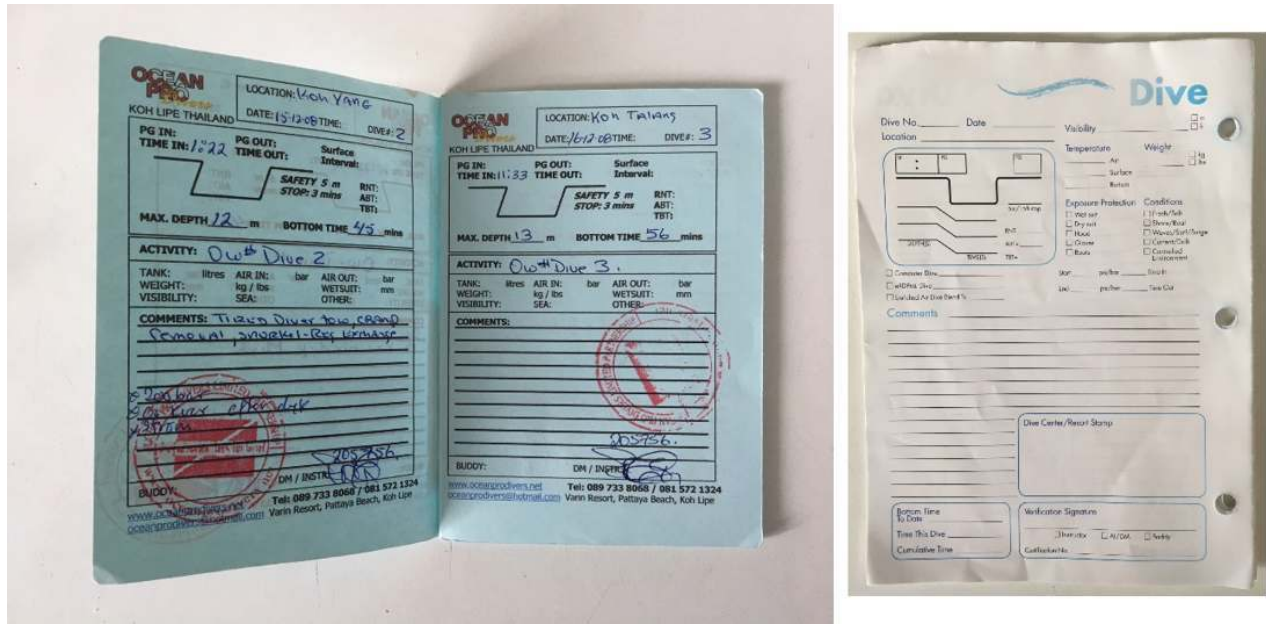

Image to the left is from one of the author's logbooks, and to the right an empty sheet from another logbook.

Photo by Rasmus Rodineliussen.

\section{Technologies, Usability and Malfunction}

11 I woke up to the vibration of my phone realizing I got to get ready or I would miss the boat. I quickly threw my things into the bag and reached out for the camera on the shelf. Then it struck me: "I have not made any backups on these images, not at all. I should really do that right away." Looked down at the watch realizing that I simply had no time for that now. It was either bring the camera or not, backups would have to wait. I threw the camera into the bag and went out the door, down the 120 step long stair to the main street and ran down to the docks where all the other divers and the boat were getting ready. The Brazilian town Arraial do Cabo was just about waking up.

We put the diving gear on and jumped into the water. I had after all decided to bring the camera, arguing to myself: it has worked perfectly well so far, why would something happen this time? I could not have been more wrong. We descended deeper and deeper, and at about $5 \mathrm{~m}$ below surface I started to see bubbles, BUBBLES! A device designed to be waterproof should, must not, let out bubbles when under water. I quickly understood that this was it; all my images were disappearing from me, one bubble at a time.

I tell this short anecdote for two reasons. First, this is why I have not included my images of and with interlocutors in this article: they are simply no more. Luckily enough I had already discussed the material with interlocutors and still got that material to work with. Secondly, it brings us to the topic of malfunctioning technologies. Uimonen among others also talks briefly about this in her book Digital Drama (2012) where her tape recorder decided not to participate in her research any more. And, with the increasing use of technology as tools for research this might become a growing topic of concern. Although, when it is about cameras, one could just have listened to the advice every professor gives their student before fieldwork: to do backups of your material continuously. If I had done that this would only have been the loss of my camera but not my material. 
14 It is easy to think that 'this does not happen to me', I can do that backup later, and so on. These are only excuses that open possibilities for loss of important material, and if thinking about it, how much time does it really take to copy these images to a hard drive or upload them to a 'cloud' service? In my case it was not the time that compelled me not to do backups, I simply did not think about it. I had another camera with me for 'on land' use and interestingly enough I made backups of that one, but not on the 'waterproof' camera. Perhaps this can be explained by the fact that my action camera was part of my diving equipment and as such it never occurred to me to copy that material.

15 My loss of material can serve as a reminder that when your professor, or a colleague, suggest that you do backups, they do so with good reason. As one of the editors for this journal, Beate Engelbrecht, told me in a surprised reaction during our conversation about this article: she makes backups at the end of every day, usually twice. And I urge everyone to follow her example, I too am now very attentive to always hold an extra copy of every file, may it be a picture, word doc, or anything else of little or large importance.

\section{Underwater Ethnography in Practice}

16 At first sight doing ethnography under water seems rather similar to its land-based counterpart (eg. Hammersely and Atkinson 2003; Davies 2008). However, being under water poses some constrains on the 'usual' way of doing things. First of all, it is not possible to bring a notebook for field notes. You could, in theory, bring a writing board; although, it is rather clumsy and will most likely distract more than help you. Thus, we need another way of documenting what we observe. Another aspect is directly connected to observing - your vision is limited under water. In some waters visibility can reach up to 30 , even 40 meters, but this is in exceptionally clear water. In Nordic countries your visibility will most likely be closer to 3 meters. How then, can we observe and document under water? 
Image of the author during a dive in Crete, Greece.

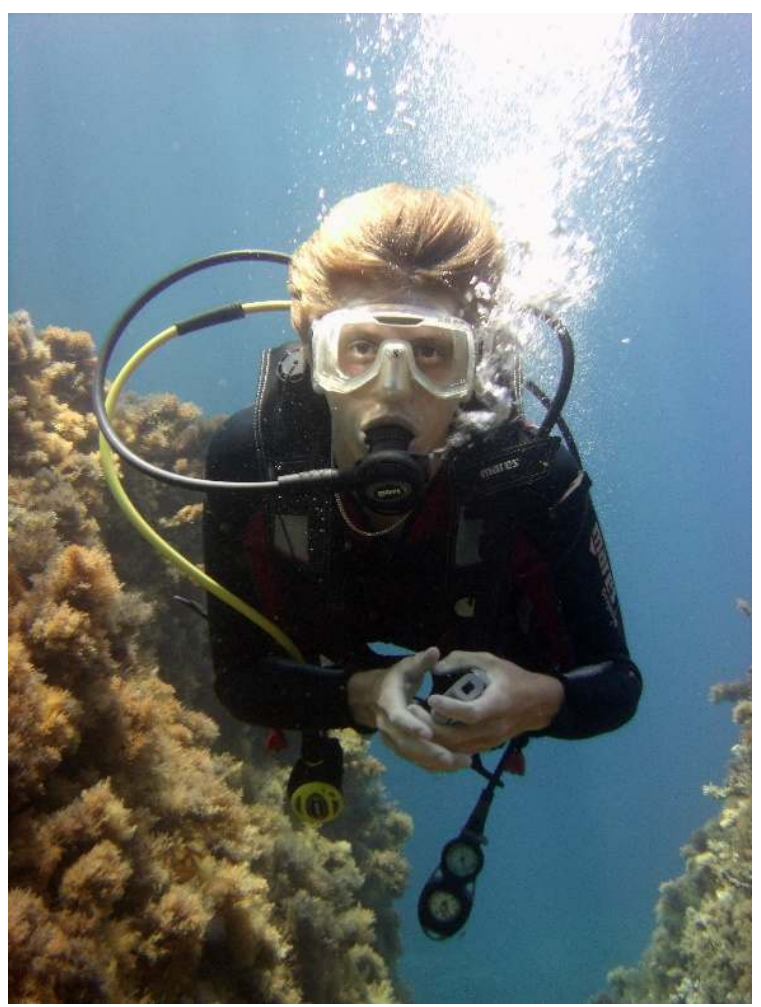

Photo by an anonymous dive master.

In my opinion the most sufficient way is to bring a camera with you - in case you do backups of your material of course. Merchant (2011b) discusses this methodological approach to some degree - her work is also scuba diving related. Merchant uses the term "video ethnography" to describe the practice of filming the way interlocutors act. Included in this method is a video showing exactly what interlocutors did and the surroundings within which they acted. Moreover, after a dive interlocutors are first asked to retell their experiences from the dive, and thereafter they are shown the video and once again asked to guide the researcher through their dive: explaining what they did, felt, and thought. Using this method allows the researcher to first experience the same bodily conditions as the interlocutors while observing the way they act. Then gaining further information on the experiences of the interlocutors during the post-dive interview, and last but not least, further inquire with the help of the video. By these means it is possible for a researcher to document, interview, and double-check both his/ her own observations and the interview answers when showing the video. The last step is a so-called video-elicitation, meaning that the researcher shows images or videos to the interlocutor in order to help her or him to remember certain moments (Rose 2007; Merchant 2011b; Maaker 2000: 185). This aspect, showing the image/video to interlocutors, is part of the so-called "filming relation": that those being filmed at some point will want to see and engage with the footage (Larcher and Oxley 2015: 1; Maaker 2000). Larcher and Oxley (2015) points out that showing images to interlocutors also tests the representation intended by the researcher, because the interviewee might want to be represented differently. On a similar note Uimonen (2013: 129-130) shows how framing is a way of showing some aspects of one's self in a selective presentation of images. This 
presentation is included in a larger context of other similar chosen presentations such as news flow on social media, and it is therefore subjective and possibly contested. This complication of representation, if I may call it that, is increasingly possible due to the expansion of internet and especially how images flow freely in social media interlocutors, from wherever, are becoming more and more aware of what images and videos on them might tell others about them, and how visible these visuals tend to become (Favero 2007: 66). Thus, photo-elicitation is a very informative method, and it can assist the researcher to understand practices observed and filmed, but it requires that the researcher has been extra clear with interlocutors beforehand on what the research and the footage is about and how the material is going to be used. This however is nothing new, research ethics and the notion of informed consent has long required this of researchers.

Merchant (2011b) illustrates another negotiation between researcher and interlocutor when she explains that sometimes her interlocutors questioned her choice of frame and focus in the videos. Hence, it is possible that a researcher film what she/he presuppose are the most important parts, meanwhile interlocutors believe other aspects are more important. One way to overcome this is to give the interlocutor control of the camera. Uimonen (2012: 217) did this with her interlocutors at an art college in Tanzania. Her interlocutors were given the camera and allowed to 'show' their world to the researcher. Uimonen has described the outcome of this method as "reflexive video narratives", pointing at the fact that interlocutors do not film unreflexively, but tell a story by the way they use the camera. When giving the interlocutor the camera it can be done with the directions to 'film this or that' or it can be just giving the interlocutor the camera without any guidance as of what to record (Uimonen 2012: 218). The second option returns us to the quote from Favero (2017) in the beginning of this article. That is, by letting the camera become as one with the researcher or the interlocutor, allowing for aimless recordings it opens up possibilities to simply experience the dive together with the interlocutor when later looking at the video together. Further, as Ferrarini (2017) explains, in order to create a sensorial ethnography using visual methods it is first essential that the video or the image is embodied by the researcher/filmmaker, using the body as a tool and allowing the camera to become one with the body. Doing this allows the researcher to both observe the interlocutor under water, and then watch together with the interlocutor what aspects of the dive deemed, or felt, important by the interlocutor (for examples of other researchers using this approach see: Pink 2006, 2009; Rose 2007). As Latour (2005) has it, the camera becomes an actor rather than a tool, mediating the sensorial experience between researcher and interlocutor. All these aspects lead to a question about 'framing', which require some elaboration.

\section{Frame, Framing, and Collaboration}

19 Merchant (2011b) writes that her interlocutors sometimes disagreed with her way of filming them, and so did mine in Brazil at some occasions. "You film sort of the right things, but you focus not on the things I would, you try to catch the bigger picture, I would zoom into the details". The next dive I handed the camera to the same interlocutor, asking him to film our dive in the way he thought it should be done. And just as he had told, his focus was much more detailed, zooming in on small details such as a tiny piece of plastic caught in a coral. Details that was lost in my larger frame. 
Henceforth I tried to film both the large - to catch the movements of the diver - and small - to catch what the divers looked and aimed at. By both discussing 'my' video with the interlocutor, and allowing them to 'show' me how they wanted it done I could develop my method to become more interlocutor oriented.

An image is a chosen part of reality, one that has been framed and selected by the photographer. Hannerz (2004: 103) writes about the concept "story line" to explain how journalists 'pick their' story in order to present a certain version for their readers. To me this is a similar process as when the photographer frames a picture. David McDougall (2005) argues that due to the representational power of images they are loaded with potential, which can be troublesome or beneficial, depending on how the representation is captured and framed. For this reason most images within anthropology and similar disciplines have been contextualized by words to direct the message.

Larcher and Oxley (2015) argue that new technology such as small and uncomplicated cameras as well as the development of the Internet and social media have resulted in increased knowledge among interlocutors of the representational power of images (Favero 2007). Thus, showing the researcher how to film has two dimensions. First, it can truly be an intent to direct the researcher to see things in the same way as the interlocutor. But it could also be an attempt by the interlocutor to reverse the power relation - taking the role as 'knower' from the researcher and become the one directing the footage and thereby the research and future representations thereof. When handing over the camera to the interlocutor it is a sort of methodological collaborative ethnography. And as such it is not new, collaboration between ethnographer and interlocutor/research subjects can be traced all the way back to Franz Boas and the like. However, as Lassiter (2005: 95) points out, during close collaboration rather complicated discussion on representation and interpretation can occur. Continuing on this, Collins et al. (2017) argue that currently the development of technology, and especially the Internet and social media have created a scenario where research subjects often know as much as, or can access the same information as the anthropologist. This should not be seen as an obstacle, but instead as a new opportunity to integrate interlocutors in research and to reach a broader public. Yet, researchers must be aware of the current knowledge situation where interlocutors are not as distant to the researcher as they used to be. Methods, ethnographic practices, writing, and dissemination of research must be adapted to such a scenario. Collins et al. (2017) even propose that knowledge produced through research should be "shared" rather than disseminated to interlocutors, doing so in the "real time" that social media provides and allows regardless of the geographical location of researcher and research subject at the time. This 'sharing' should be done continuously throughout the research and the so-called writing up. Doing so will allow the interlocutor to both comment on the material and the thoughts of the researcher as well as answer further inquiries as they surface.

\section{Conclusion}

In this article I have proposed to study the social group of scuba divers by following them into the environment that they love, employing the concept of underwater ethnography. I have mentioned some possibilities of how to undertake this endeavour methodologically and suggested that using visual methods might be the most appropriate and effective way 
to go about it. I have also emphasised the importance of doing backups of your visual material as you go along.

\section{BIBLIOGRAPHY}

Bourdieu, P. 1990. The Logic of Practice. Oxford: Polity Press.

Broady, D. 1991. Kapitel III. Nyckelbegrepp, in Sociologi och epistemologi. Om Pierre Bourdieus författarskap och den historiska epistemologin, 2 uppl. HLS förlag: Stockholm.

Collins, S.G., Durington, M., Favero, P., Harper, K., Kenner, A. and O'Donnell, C. 2017. Ethnographic Apps/Apps as Ethnography. Anthropology Now. Vol. 9(1): 102-118.

Davies, C. A. 2008. Reflexive Ethnography a Guide to Research Selves and Others. London, New York: Routledge.

Favero, P. 2007. 'What a Wonderful World!': On the 'Touristic Ways of Seeing, the Knowledge and the Politics of the 'Culture Industries of Otherness'. Tourist Studies. Vol. 7(1): 55-81. 
Favero, P. 2017. 'The Transparent Photograph' Reflections on the Ontology of Photographs in a Changing Digital Landscape. RAI, Anthropology \& Photography. Vol.7.

Ferrarini, L. 2017. Embodied Representation: Audiovisual Media and Sensory Ethnography. AnthroVision. Vol. 5(1). https://journals.openedition.org/anthrovision/2514 (accessed 29 January, 2019).

Gherardi, S. 2016. To Start Practice Theorizing Anew: The Contribution of the Concepts of Agencement and Formativeness. Organization. Vol. 23(5): 680-698.

Hammersley, M. and Atkinson, P. 2003. Ethnography, Principles in Practice. Third edition. London: Routledge.

Hannerz, U. 2004. Foreign News: Exploring the World of Foreign Correspondents. Chicago: The University of Chicago Press.

Haraway, D., Ishiwawa, N. Gilbert, S. F., Olwig, K., Tsing, Anna L., and Bubandt, N. 2015. Anthropologists Are Talking - About the Anthropocene. Ethnos. Vol. 81(3): 535-564.

Hawkins, J. P., Callum M. R., David, K., Buchan, K. \& White, S. 2005. Sustainability of Scuba Diving Tourism on Coral Reefs of Saba. Coastal Management. Vol. 33(4): 373-387.

Herzfeld, M. 2007. Senses. In Ethnographic Fieldwork: An Anthropological Reader. Antonius C. G. M. Robben, and A Jeffrey eds. Pp. 431-441.Malden, MA. Blackwell.

Karlsson, B. G. 2018. After Political Ecology. Review. Anthropology Today. Vol 34(2): 22-24.

Larcher, J., and Oxley, N. 2015. Current Dilemmas of the Ethnographer behind the Camera. AnthroVision. Vol. 3(2). https://journals.openedition.org/anthrovision/1572 (accessed 29 January, 2019).

Lassiter, L. C. 2005. Collaborative Ethnography and Public Anthropology. Current Anthropology. Vol. 46(1): 83-106.

Latour, B. 2005. Reassembling the Social: An Introduction to Actor-Network-Theory. Oxford: Oxford University Press.

Lien, M. E. 2015. Becoming Salmon. Aquaculture and the Domestication of Fish. California Studies in Food and Culture. California: U.C. Press.

Lück, M. 2016. Scuba Diving Tourism. Annals of Leisure Research. Vol. 19(2): 259-261.

MacDougall, D. 2005. The Corporeal Image. Princeton: Princeton University Press.

Maaker, E. 2000. Integrating Ethnographic Research and Filmmaking: Video Elicitation for a Performance-Oriented Analysis of the Teyyam Ritual. Visual Anthropology. Vol. 12(2): 186-197.

Merchant, S. 2011a. Negotiating Underwater Space: The Sensorium, the Body and the Practice of Scuba-diving. Tourist Studies. Vol. 11(3): 215-234.

Merchant, S. 2011b. The Body and the Senses: Visual Methods, Videography and the Submarine Sensorium. Body and Society. Vol. 17(1): 53-72.

Musa, G., and Dimmock, K. 2013. Scuba Diving Tourism. Abingdon/New York: Routledge.

Pink, S. 2006. The Future of Visual Anthropology: Engaging the Senses. Oxford: Taylor \& Francis.

Pink, S. 2009. Doing Sensory Ethnography. London: Sage.

Rodineliussen, R. 2017. Divers Engaging Policy-Practices of Making Water. Stockholm University and SIDA. 
Rose, G. 2007. Visual Methodologies: An Introduction to the Interpretation of Visual Materials. London:

Sage.

Stoller, P. 1989. The Taste of Ethnographic Things: The Senses in Anthropology. Philadelphia:

University of Pennsylvania Press.

Stoller, P. 1997. Sensous Scholarship. University of Pennsylvania Press: Philadelphia.

Uimonen, P. 2012. Digital Drama. Teaching and Learning Art and Media in Tanzania. New York:

Routledge.

Uimonen, P. 2013. Visual Identity in Facebook. Visual Studies. Vol. 28(2): 122-135.

Wacquant, L. J. D. 2004. Body and Soul. Oxford: Oxford University Press.

\section{ENDNOTES}

1. Meaning a diver that dive for recreational purposes, on holidays, not as a professional.

2. https://www.padi.com/sites/default/files/documents/2017\%20PADI\%20WW\%20Statistics.pdf (accessed 29 January, 2019)

3. Buoyancy Control Device

\section{ABSTRACTS}

In this article I engage in a discussion regarding how and why to conduct underwater ethnography when studying the social group of scuba divers. The material presented was collected during fieldwork in Brazil 2016/2017, as well as from the researchers own decade long experience of being a recreational diver. The discussion touches on the methodological approach of using a camera to document and engage with a sensorial experience. Furthermore, aspects of power, representation, and framing of images are brought up, noting how the increasing circulation of visual materials has made interlocutors more aware of the way they are represented visually. I also elaborate on the importance of doing backups of your material. Lastly, the aim of this article is to call for further exploration of the scuba diving community and their underwater practices.

En este artículo planteo una discusión acerca de cómo y por qué realizar una etnografía submarina al estudiar el grupo social de los buceadores. El material presentado se recopiló durante un trabajo de campo realizado en Brasil entre 2016 y 2017, así como a partir de la experiencia del investigador como buceador recreativo durante una década. La discusión aborda el enfoque metodológico del uso de una cámara para documentar y participar en una experiencia sensorial. Además, se ponen encima de la mesa aspectos relativos al poder, a la representación y al encuadre de las imágenes, observando cómo el aumento de la circulación de los materiales visuales ha hecho que los interlocutores sean más conscientes de la forma en que son representados visualmente. También me refiero a la importancia de hacer copias de seguridad del material. Por último, el objetivo de este artículo es reivindicar una mayor exploración de la comunidad de buceo y de sus prácticas submarinas. 
INDEX

Palabras claves: métodos visuales, etnografía subacuática, buceo, Brasil, imágenes, agua Mots-clés: Mots-cles

Keywords: visual methods, underwater ethnography, Scuba diving, Brazil, images, water

\section{AUTHOR}

\section{RASMUS RODINELIUSSEN}

Department of social anthropology, Stockholm University.

Rasmus.rodineliussen@gmail.com 